\title{
Penggunaan Multimedia Interaktif Model Tutorial Dalam Meningkatkan Motivasi Dan Hasil Belajar Pada Pembelajaran Menulis Bahasa Inggris
}

\author{
Saepulloh $^{1}$ Erna Srirahayu ${ }^{2}$ Nurparida $^{3}$ \\ abi03nazwa@gmail.com ernasrirahayu9@gmail.com nurparida9@gmail.com
}

\begin{abstract}
Abstrak
Salah satu keterampilan yang paling sulit dikuasai peserta didik adalah keterampilan menulis (writing). Penelitian ini dilatar belakangi oleh rendahnya hasil belajar dan motivasi belajar siswa pada pembelajaran bahasa Inggris. Tujuan penelitian ini adalah untuk mengetahui peningkatan motivasi dan hasil belajar siswa dengan menggunakan multimedia interaktif model tutorial pada pembelajaran bahasa inggris. Metode penelitian yang digunakan adalah quasi eksperimen dengan desain Nonequivalent Control Group Design. Hasil penelitian menunjukan berdasarkan dari hasil uji gain peningkatan motivasi belajar siswa pada kelas eksperimen sebesar 0,70 dengan kategori tinggi dan kelas control sebesar 0,31 dengan aktegori sedang artinya peningkatan motivasi belajar pada kelas eksperimen dengan menggunakan media interaktif model tutorial lebih tinggi dibandingkan dengan pembelajaran konvensional. Hasil uji hipotesis nilai Asymp Sig. (2-tailed) $=0,000$ lebih kecil dari $\alpha=0,05$ maka Ha diterima maka dapat disimpulkan bahwa terdapat perbedaan peningkatan hasil belajar antara kelas eksperimen dengan menggunakan multimedia interaktif tutorial dan kelas control dengan pembelajaran menggunakan metode ceramah

Kata Kunci : multimedia interaktif tutorial; motivasi belajar; hasil belajar
\end{abstract}

\section{PENDAHULUAN}

Pendidikan adalah usaha sadar dan terencana untuk mewujudkan suasana belajar dan proses pembelajaran agar peserta didik secara aktif mengembangkan potensi dirinya untuk memiliki kekuatan spiritual keagamaan, pengendalian diri, kepribadian, kecerdasan, akhlak mulia, serta keterampilan yang diperlukan dirinya, masyarakat, bangsa dan Negara (UU No. 20 Tahun 2003). Pendidikan yang bermutu adalah pendidikan yang mampu menghasilkan lulusan yang memiliki kemampuan atau kompetensi akademik yang dilandasi oleh kompetensi personal dan sosial, serta nilai-nilai akhlak mulia, yang keseluruhannya merupakan kecakapan hidup (life skill). Pendidikan bermutu adalah pendidikan yang mampu menghasilkan manusia seutuhnya (manusia paripurna) atau manusia dengan pribadi yang integral (integrated personality) yaitu mereka yang mampu mengintegralkan iman, ilmu, dan amal [1].
Pembelajaran merupakan usaha sadar dari guru untuk membuat siswa belajar, yaitu terjadinya perubahan tingkah laku pada diri siswa yang belajar, dimana perubahan itu dengan didapatkannya kemampuan baru yang berlaku dalam waktu yang relatif lama dan karena adanya usaha. Pembelajaran adalah proses interaksi peserta didik dengan pendidik dan sumber belajar pada suatu lingkungan belajar. Pentingnya peran guru memahami sebaik-baiknya tentang proses belajar siswa, agar dapat memberikan bimbingan dan menyediakan lingkungan belajar yang tepat dan serasi bagi siswa [2].

Proses komunikasi dikelas antara peserta didik dengan guru maupun peserta didik dengan peserta didik merupakan bagian interaksi guna mewujudkan tujuan pembelajaran yang diharapkan. Dalam proses pembelajaran bahasa dalam kehidupan nyata ada perbedaan yang sangat mendasar antara ragam bahasa lisan dan tulisan. Seseorang dikatakan berhasil atau mahir dalam suatu bahasa apabila telah menguasai 4 skill of language, yaitu menyimak (listening), 
berbicara (speaking), membaca (reading), dan menulis (writing). Keterampilan yang paling sulit dikuasai peserta didik adalah keterampilan menulis (writing) karena dalam menulis mereka harus menguasai tata bahasa dengan baik dan perbendaharaan kosakata yang banyak. Untuk mengatasi masalah tersebut, seorang guru dituntut untuk menciptakan proses pembelajaran yang inovatif mencakup pembaruan strategi pembelajaran dan media pembelajaran. Multimetode tutorial merupakan bagian dari media pembelajaran memuat unsur-unsur gambar, video, suara, teks, dan animasi yang menyajikan informasi berkenaan dengan tahapan-tahapan melakukan aktivitas belajar dalam mencapai tujuan pembelajaran tertentu. Tujuan penelitian ini adalah untuk mengetahui peningkatan motivasi dan hasil belajar siswa dengan menggunakan multimedia interaktif model tutorial pada pembelajaran bahasa inggris. Beberapa hasil penelitian menunjukan pengaruh dan perubahan yang signifikan dalam pembelajaran menggunakan multimedia tutorial, [3].

Berdasarkan uraian latar belakang masalah diatas, maka rumusan masalah dalam penelitian ini (1) Apakah multimedia interaktif model tutorial dapat meningkatkan motivasi belajar dan hasil belajar siswa pada pembelajaran bahasa Inggris di MTs Al Yusufiyah Leuwigoong? (2) Apakah terdapat perbedaan peningkatan hasil belajar siswa antara peserta didik yang mendapat penggunaan multimedia interaktif model tutorial dan peserta didik yang menggunakan pembelajaran konvensional di MTs Al Yusufiyah Leuwigoong?

\section{Multimedia Interaktif Model Tutorial}

Multimedia merupakan perpaduan antara berbagai media (format file) yang berupa teks, gambar (vektor atau bitmap), grafik, sound, animasi, video, interaksi, dan lain-lain yang telah dikemas menjadi file digital (komputerisasi), digunakan untuk menyampaikan pesan kepada public[4]. Multimedia dapat berupa audio (suara, musik), animasi, video, teks, grafik dan gambar [5]. [6]multimedia merupakan kombinasi teks, seni suara, gambar, animasi, dan video yang disampaikan dengan komputer atau dimanipulasi secara digital dan dapat disampaikan danatau dikontrol secara interaktif [6]. Berdsarkan pendapat para ahli diatas, dapat disimpulkan bahwa multimedia merupakan perpaduan media berupa teks, seni suara, gambar, animasi, dan video dalam satu kesatuan untuk menyampaikan pesan.

Multimedia interaktif adalah suatu multimedia yang dilengkapi dengan alat pengontrol yang dapat dioperasikan oleh pengontrol yang dapat dioperasikan oleh pengguna, sehingga pengguna dapat memilih apa yang dikehendaki untuk proses selanjutnya tanpa berurutan [7]. Jenis multimedia interaktif, dimana pengguna dapat menekan mouse atau objek pada screen seperti button atau teks dan menyebabkan program melakukan perintah tertentu [8].

Multimedia interaktif model tutorial adalah pembelajaran melalui komputer dimana siswa dikondisikan untuk mengikuti alur pembelajaran yang sudah terprogram dengan penyajian materi dan latihan soal. Model tutorial berisi : tujuan, materi dan evaluasi, yang bertujuan untuk memberikan pemahaman secara tuntas (masteri learning) kepada siswa mengenai materi pelajaran yang dipelajari. Menurut [9] dalam melaksanakan tahapan proses produksi Computer Assisten Instruction (CAI) model tutorial hendaknya memperhatikan struktur ; 1 ). pengenalan (introduction); 2) penyajian Informasi (presentation of information); 3) pertanyaan dan respons-respons (Question of responses); 4) penilaian Respons (judging of responses), 5) pemberian balikan respons (providing feedback about responses); 6) pengulangan (remediation); 7) segment pengaturan pelajaran (sequencing lesson segment); 8) penutup (closing).

\section{Motivasi Belajar}

Motivasi akar katanya adalah motif. Motif menunjukkan suatu dorongan yang timbul dari dalam diri seseorang yang menyebabkan orang tersebut mau bertindak melakukan sesuatu [10]. Motivasi adalah pendorong yaitu usaha yang disadari untuk mempengaruhi tingkah laku seseorang agar dia tergerak hatinya untuk bertindak melakukan sesuatu sehingga sehingga agar dia tergerak hatinya untuk bertindak melakukan sesuatu sehingga mencapai hasil hatinya untuk bertindak melakukan sesuatu sehingga mencapai hasil atau tujuan tertentu. [11] menyatakan bahwa motivasi adalah segala daya yang mendorong seseorang untuk melakukan 
sesuatu. Berdasarkan pendapat para ahli diatas dapat disimpulkan bahwa motivasi belajar merupakan daya pendorong yang dimiliki peserta didik untuk melakukan aktivitas belajar.

\section{Hasil Belajar Siswa}

Mutu lulusan yang berkualitas bisa ditunjukkan dengan adanya bukti hasil belajar dan prestasi siswa sebagai suatu puncak proses belajar. Pada tahap ini siswa membuktikannya dengan keberhasilan belajar, yang mana siswa menunjukkan telah mampu memecahkan tugastugas belajar atau mentransfer hasil belajar. Hasil belajar dalam bentuk prestasi (achievement) adalah 'something accomplished, superior ability' atau sesuatu yang telah dilaksanakan dengan baik melalui usaha yang sungguhsungguh [12]. Hasil belajar adalah hasil usaha yang maksimum dicapai oleh seseorang (seorang siswa) setelah yang bersangkutan melakukan serentetan proses kegiatan belajar selama jangka waktu tertentu, baik di sekolah maupun di masyarakat.

Faktor-faktor yang mempengaruhi belajar dapat dibedakan menjadi tiga macam yaitu

faktor internal mengenai kondisi jasmani (fisiologis) dan rohani (psikologis) siswa, faktor eksternal berkenaan lingkungan dan instrumen sekitar siswa, dan faktor pendekatan belajar yakni jenis upaya belajar siswa yang meliputi strategi dan metode yang digunakan siswa untuk melakukan kegiatan pembelajaran materimateripelajaran [13]. Dalam mencapai mutu pendidikan yang diharapkan perlu dilakukan upaya-upaya penerapan strategi produktivitas pendidikan yang dapat dilakukan melalui halhal [14] sebagai berikut :

a. Merancang secara terus menerus berbagai tujuan pengembangan siswa, pegawai, dan layanan pendidikan;

b. Mengedepankan kualitas pembelajaran dan kualitas kerja;

c. Guru harus menyediakan pengalaman pembelajaran yang menghasilkan kualitas kerja;

d. Menjalin kerja sama yang baik dengan pihak-pihak yang berkepentingan untuk menjamin penerimaan input berkualitas;

e. Melakukan evaluasi secara kontinyu dan mencari terobosan-terobosan pengembangan sistem dan proses untuk meningkatkan mutu dan produktivitas; f. Tenaga kependidikan dan peserta didik harus dilatih dalam pengembangan mutu;

g. Kepemimpinan sekolah mampu mengarahkan sumber daya sekolah mengerjakan tugas pekerjaannya dengan lebih baik;

h. Mengembangkan kemampuan menemukan masalah dan cara pemecahannya.

\section{METODE}

Dalam penelitian ini, peneliti menggunakan desain penelitian kuasi eksperimen Nonequivalent Control Group Design yang kelompok eksperimen maupun kelompok kontrol tidak dipilih secara random [15]. Ada perbedaan dalam pemberian perlakuan pada kelas eksperimen dan kelas control. Kelompok eksperimen diberikan perlakuan multimedia interaktif tutorial dan kelompok control dengan menggunakan metode ceramah. Populasi dan dampel penelitian ini adalah siswa kelas VII sebanyak 76 siswa.

\section{HASIL DAN PEMBAHASAN}

Berdasarkan hasil uji gain mengenai peningkatan motivasi belajar pada kelas eksperimen dan kelas control diperoleh data sebagai berikut:

Tabel 1. Perbandingan Peningkatan Prestasi Belajar

\begin{tabular}{llllc}
\hline & \multicolumn{1}{c}{ Kelas } & $\mathrm{N}$ & Mean & Gain.Ternm \\
\hline \multirow{2}{*}{ Gain } & Eksperimen & 38 & 40.28 & 0.70 \\
& Kontrol & 38 & 25.63 & 0.31 \\
\hline
\end{tabular}

Berdasarkan dari hasil uji gain peningkatan motivasi belajar siswa pada kelas eksperimen sebesar 0,70 dengan kategori tinggi dan kelas control sebesar 0,31 dengan aktegori sedang (Meltzer, 2002) artinya peningkatan motivasi belajar pada kelas eksperimen dengan menggunakan media interaktif model tutorial lebih tinggi dibandingkan dengan pembelajaran konvensional. [16] menjelaskan bahwa : (a) media pembelajaran merupakan wadah dari pesan, (b) materi yang ingin disampaikan adalah pesan pembelajaran, (c) tujuan yang ingin dicapai adalah proses pembelajaran. Selanjutnya penggunaan media secara kreatif akan memperbesar kemungkinan bagi peserta didik untuk belajar lebih banyak, mencamkan apa yang 
dipelajarinya lebih baik, dan meningkatkan penampilan dalam melakukan keterampilan sesuai dengan tujuan pembelajaran sehingga jelas bahwa penggunaan multimedia interaktif model tutorial dapat meningkatkan motivasi yang tinggi pada peserta didik dibandingkan dengan peserta didik yang hanya mengandalkan teknik verbal dan ceramah. Penggunaan Multimedia Interaktif Model Tutorial memberikan nilai efektifitas baik terhadap motivasi dan hasil belajar peserta didik dibandingkan dengan pembelajaran dengan penggunaan direct instructional [17].

Berdasarkan hasil uji hipotesis nilai Asymp Sig. (2-tailed) $=0,000$ lebih kecil dari $\alpha=$ 0,05 maka Ha diterima maka dapat disimpulkan bahwa Terdapat perbedaan peningkatan hasil belajar antara kelas eksperimen dengan menggunakan multimedia interaktif tutorial dan kelas control dengan pembelajaran menggunakan metode ceramah. Kondisi tersebut dapat dinyatakan bahwa penggunaan multimedia interaktif model tutorial lebih baik dibandingkan dengan pembelajaran dengan metode ceramah dalam meningkatkan hasil belajar siswa. [9]pengembangan multimedia interaktif untuk pembelajaran diantaranya : (1) analisis kebutuhan, (2) identifikasi masalah, (3) identifikasi materi, (4) menentukan model pembelajaran, (5) desain flowchart, (6) penulisan storyboard, (7) pengumpulan bahan grafis, (8) pengumpulan bahan animasi, (9) pemrograman, (10) finishing, (11) uji coba, (12) revisi produk akhir, dan (13) penerapan produk.

Multimedia interaktif tutorial menyajikan informasi/materi yang konkret mengenai prosedur penerapan teori maupun konsep dalam melakukan aktivitas belajar siswa sehingga materi yang bersifat abstrak dapat dijelaskan menjadi konkret dan meminimalisir penyampaian materi secara verbal. Senada dengan Edgar Gale [18] akan semakin abstrak apabila hanya disampaikan dalam bahasa verbal'. Hal ini memungkinkan terjadinya verbalisme, artinya siswa hanya mengetahui tentang kata tanpa memahami dan mengerti makna yang terkandung dalam kata tersebut. Sebaiknya diusahakan agar pengalaman siswa menjadi lebih konkret artinya pesan yang ingin disampaikan benar-benar dapat mencapai sasaran dan tujuan yang ingin dicapai dengan cara mendekatkan siswa pada kondisi yang sebenarnya.

\section{KESIMPULAN}

Berdasarkan hasil penelitian diatas, penggunaan multimedia interaktif model tutorial dapat meningkatkan motivasi dan hasil belajar siswa dibandingkan dengan pembelajarn menggunakan metode ceramah. Terdapat kelebihan-kelebihan dari penggunaan multimedia interaktif model tutorial disamping ada beberapa hal yang perlu diperhatikan dalam penyusnan dan penerapan media pembelajaran diantaranya ketersediaan fasilitas pendukung, karakteristik mata pelajaran/materi pelajaran, karakteristik peserta didik, dan sumberdaya pendukung lainnya.

\section{Daftar Pustaka}

[1] S. Subana, Dasar-Dasar Penelitian Ilmiah. Bandung: Pustaka Setia, 2005.

[2] O. Hamalik, Kurikulum dan Pembelajaran. Jakarta: Bumi Aksara, 2010.

[3] "Nurparida T. 2012. Pengaruh Penggunaan Multimedia Pembelajaran terhadap Peningkatan Motivasi Siswa dalam Pembelajaran Bahasa inggris pada Pembelajaran menulis . Tesis Pada Sekolah Tinggi Keguruan dan Ilmu Pendidikan Garut: Tidak Diterbitkan.," 2012.

[4] D. Ariani, N dan Haryanto, "Pembelajaran Multimedia Di Sekolah Pedoman Pembelajaran Inspiratif, Konstruktif dan Prospektif . Jakarta: PT Prestasi Pustaka.," 2010.

[5] "Turban E., King D., Lee J., Warkentin M. and Chung H.M. (2002). Electronic Commerce 2002 - A Managerial Perspective (Second edition). New York: Prentice Hall.," p. 2002, 2002.

[6] Binanto, Multimedia Digital Dasar Teori + Pengembangan. Yogyakarta: CV Andi Offset, 2010.

[7] "Smaldino. Sharon. E. (2012). Intructional Technology and Media for Learning. Penterjemah: Arief Rahman. Jakarta: Kencana," p. 2012, 2012.

[8] A. H. Sutopo, Teknologi Informasi dan Komunikasi dalam Pendidikan. Yogyakarta: Graha Ilmu. Yogyakarta: Graha Ilmu, 2012.

[9] D. Darmawan, "Metode peneletian kuantitatif," vol. April, p. 130, 2019, 
Saepulloh ${ }^{1}$ Erna Srirahayu ${ }^{2}$ Nurparida $^{3}$ Penggunaan Multimedia Interaktif Model Tutorial dalam Meningkatkan Motivasi dan Hasil Belajar Pada Pembelajaran Menulis Bahasa Inggris

[Online]. Available: rosda.org.

[10] Moekiyat, Dasar-Dasar Motivasi.

Bandung: Pioner Jaya, 2001.

[11] A. M. Sardiman, Interaksi dan Motivasi Belajar Mengajar. Jakarta: Rajawali Press, 2011.

[12] "Collins, W. 2009. Collins English Dictionary : Complete and Unabridged . 10th Edition. London : William Collins Sons and Co. Ltd. And Harper-Collins Publishers," p. 2009, 2009.

[13] M. Syah, Psikologi Belajar. Jakarta: Raja Grafindo Persada, 2004.

[14] "Umaedi. 1999. Manajemen Peningkatan Mutu Berbasis Sekolah . Jakarta :

Ditmenum, Ditjen Dikdasmen, Depdiknas, April 1999," no. April, p. 1999, 1999.

[15] Sugiyono, Statistika untuk Penelitian. Bandung: Alfabeta, 2010.

[16] C. Susilana, Rudi, Riyana, Media Pembelajaran. Bandung: CV Wacana Prima, 2009.

[17] E. Sobarna, "Efektifitas Penggunaan Multimedia Interaktif (Mmi) Model Tutorial Terhadap Motivasi Serta Hasil Belajar Peserta Didik Pada Materi Pelajaran Ilmu Pengetahuan Alam Pokok Bahasan Sistem Pernapasan Manusia," Edutech, vol. 13, no. 3, p. 386, 2014, doi: 10.17509/edutech.v13i3.3092.

[18] W. Sanjaya, "Sanjaya, Wina. 2006. Strategi Pembelajaran Berorientasi Standar Proses Pendidikan,” p. 2010, 2006. 